\title{
New materials for luminescent scanning near-field microscopy
}

\author{
V. Chornii*, O. Chukova*, Yu. Hizhnyi ${ }^{*}$, S.G. Nedilko*, \\ S.A. Nedilko*, K. Terebilenko*, M. Slobodyanik, L. Aigouy ${ }_{* * *}^{* *}$, \\ L. Billot ${ }^{* * *}$, V. Boyko ${ }^{* * * *}$, S. Virko ${ }^{* * * * *}$, O. Gomenyuk \\ "T. Shevchenko National University of Kyiv, \\ 64/13 Volodymyrska St., Kyiv, 01601, Ukraine \\ **:Laboratoire de Physique et d'Etude des Materiaux, ESPCI-CNRS UMR \\ 8213, 10 rue Vauquelin, Paris, 75231, France \\ National University of Life and Environmental Science of Ukraine, \\ 15 Geroiv Oborony St., Kyiv, 03041, Ukraine \\ *:*** V.Lashkaryov Institute for Semiconductor Physics, National Academy \\ of Sciences of Ukraine, of Ukraine, 41, pr. Nauki, Kyiv, 03028, Ukraine \\ Glukhiv National Pedagogical University, \\ 24 Kyjevo-Moskovs'ka St., Glukhiv, 41400, Ukraine
}

Received May 25, 2013

\begin{abstract}
Results on synthesis and characterization of the luminescent probes for applications in determination of near-field optical characteristics and spatial distribution of local temperature are presented. Two types of materials are studied: $\mathrm{Eu}^{3+}$ doped vanadates $\mathrm{LaVO}_{4}$, and chromium-doped composites $\left(\mathrm{NaAl}\left(\mathrm{MoO}_{4}\right)_{2} / \mathrm{Al}_{2} \mathrm{O}_{3}\right): \mathrm{Cr}$. It was shown that submicron-sized particles of the mentioned materials can be used for development of the luminescent probes for near-field optical applications.
\end{abstract}

Представлены результаты синтеза и исследования характеристик люминесцентных зондов для исследования характеристик ближнего поля и пространственного распределения локальной температуры. Исследованы два типа материалов: ванадаты $\mathrm{LaVO}_{4}$, легированные люминесцентными ионами $\mathrm{Eu}^{3+}$ и композиты $\mathrm{NaAl}\left(\mathrm{MoO}_{4}\right)_{2} / \mathrm{Al}_{2} \mathrm{O}_{3}$, легированные люминесцентными ионами $\mathrm{Cr}^{3+}$. Показано, что субмикронные частицы указанных соединений могут использоваться при разработке люминесцентных зондов для ближнеполевой оптической микроскопии.

Нові матеріали для скануючой ближньопольової люмінесиентної мікроскопї. В.Чорній, О.Чукова, Ю.Хижний, С.Г.Неділько, С.А.Неділько, К.Теребіленко, М.Слободяник, Л.Егуі, Л.Білло, В.Бойко, С.Вірко, О.Голенюк.

Представлено результати синтезу та вивчення характеристик люмінесцентних зондів, придатних для визначення оптичних характеристик ближнього поля та просторового розподілу локальної температури. Досліджено два типи матеріалів: леговані іонами $\mathrm{Eu}^{3+}$ ванадати $\mathrm{LaVO}_{4}$ та композити $\mathrm{NaAl}\left(\mathrm{MoO}_{4}\right)_{2} / \mathrm{Al}_{2} \mathrm{O}_{3}$, леговані іонами $\mathrm{Cr}^{3+}$. Показано, що субмікронні частинки зазначених матеріалів можуть бути використані для розробки люмінесцентних зондів ближньопольової оптичної мікроскопії. 


\section{Introduction}

Several branches of modern technologies require the characterization of materials and components with a spatial resolution smaller than the micrometer. This concern, for instance, optical or plasmonic devices composed of nanoparticles or other nanostructured objects. For such structures, it is important to observe the localization of the optical near-field and/or to observe the propagation of surface optical waves like plasmon polaritons [1]. Similarly, in the domain of thermal science, the microelectronics industry needs to determine how nanoscale devices heat up and how their heat is released in the local environment [2]. In that case, it is important to determine the local temperature of the devices. Other applications like nanoheaters for biochemical applications [3] or like thermal modulators for integrated optical communications [4], need to be tuned in temperature very precisely in order to get the desired effects. For these applications in thermics, spatial resolution of the majority of existing contact temperature transducers (thermocouples, liquid thermometers) is limited to the sub-millimeter region, far from the expected needs [5]. This problem can be solved by using luminescence thermometry. In such technique, the temperature of the object is measured by detecting the radiation of the luminescent probe which is either introduced in the composition, set in contact or diluted inside the object if it involves a liquid. The spatial resolution is then determined by the dimensions of the luminescent probe. This probe should contain a fragment (micro- or nano-cluster) of luminescent substance that possesses a welldefined temperature-dependent emission spectrum.

In this work, results on synthesis and luminescence characterization of luminescent probes for applications in near-field optical characterization and for the measurement of local temperature are presented. We will show that submicron-sized Eu-doped vanadates particles can be used for development of the luminescent probes for near-field optical applications. We will also show that chromiumdoped composites $\left(\mathrm{NaAl}\left(\mathrm{MoO}_{4}\right)_{2} / \mathrm{Al}_{2} \mathrm{O}_{3}\right): \mathrm{Cr}$ exhibit a strong luminescence that could be used for local temperature measurements.

\section{Experimental}

Synthesis. The $\mathrm{La}_{1-\mathrm{x}} \mathrm{Eu}_{\mathrm{x}} \mathrm{VO}_{4}$, powders were synthesized by two methods, namely the Solid State method and Co-Precipitation Method. The phase composition and crystal lattice parameters were determined using $X$-ray DRON-3M $\left(\mathrm{Cu}_{K \alpha}\right.$-radiation with a $\mathrm{Ni}$ filter) and Shimadzu LabX XRD-6000 $\left(\mathrm{Cu}_{K \alpha}\right.$ -radiation) diffractometers. The microstructure of the compounds was studied with a scanning electron microscope (SEM) Hitachi S - 2400. The SEM images of the objects under investigation (Fig. 1) show particles of different shape which posess average diameter near $2 \mu \mathrm{m}$ for solid-state reaction and near $0.5 \mu \mathrm{m}$ for co-precipitation synthesis method. One can see from Fig. 1 (b) that, in the case of co-precipitation of components, the crystallite surface is more loose and porous, and the particle sizes are about four times lesser than those obtained in the case of the solid state method. Thus, it is possible to get material with powder grains of smaller sizes (about several hundreds of nanometers) applying co-precipitation procedure of synthesis.

Composites $\left(\mathrm{NaAl}\left(\mathrm{MoO}_{4}\right)_{2} / \mathrm{Al}_{2} \mathrm{O}_{3}\right): \mathrm{Cr}^{3+}$ were obtained during slow cooling of a high-temperature melts from Na-Al-Mo-O system. The phases were identified by optical microscopy, powder X-ray diffraction and IR spectroscopy. Diffraction patterns were obtained with automatic powder diffractometer Shimadzu

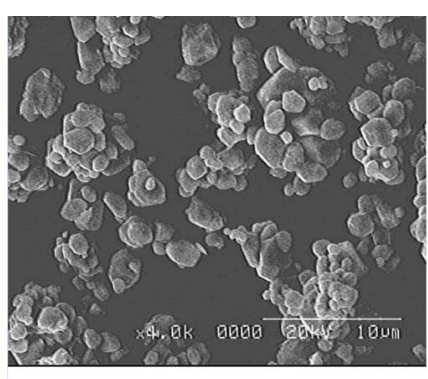

a)

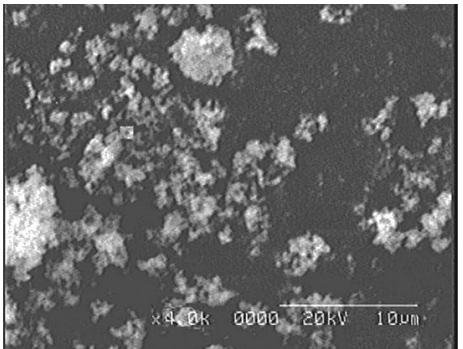

b)

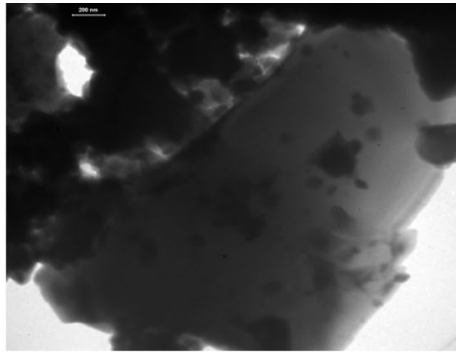

c)

Fig. 1. The SEM images of the (a) $\mathrm{La}_{1-\mathrm{x}} \mathrm{Eu}_{\mathrm{x}} \mathrm{VO}_{4}$ obtained by the solid state, $x=0.1$; (b) $\mathrm{La}_{1-\mathrm{x}} \mathrm{Eu}_{\mathrm{x}} \mathrm{VO}_{4}$ obtained by co-precipitation synthesis method, $x=0.1$; (c) composite $\mathrm{NaAl}\left(\mathrm{MoO}_{4}\right)_{2}: \mathrm{Cr}_{3}{ }^{3+} / \mathrm{Al}_{2} \mathrm{O}_{3}: \mathrm{Cr}^{3+}$ 

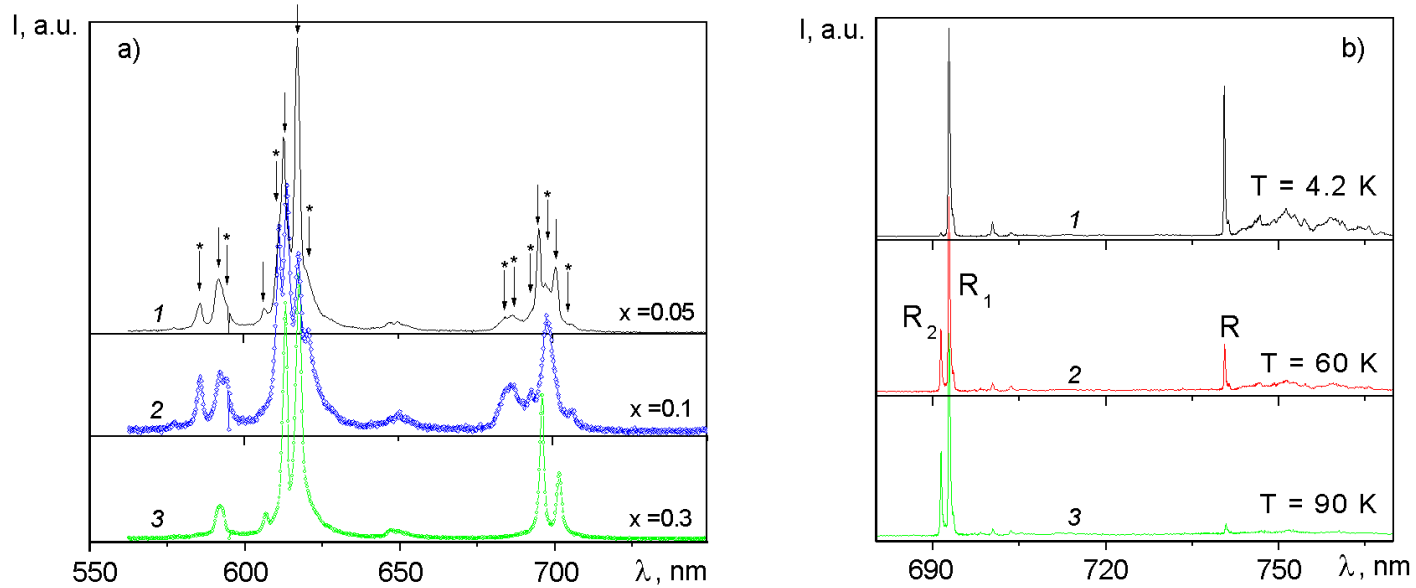

Fig. 2. Luminescence spectra of the (a) $\mathrm{La}_{1-\mathrm{x}} \mathrm{Eu}_{\mathrm{x}} \mathrm{VO}_{4}$ powders synthesized by the co-precipitation method, $T=10 \mathrm{~K}, \lambda_{e x}=300 \mathrm{~nm}, x=0.05$ (1), 0.1 (2), 0.3 (3); and (b) NaAl(MoO$)_{2}: \mathrm{Cr}^{3+} / \mathrm{Al}_{2} \mathrm{O}_{3}: \mathrm{Cr}^{3+}$ composite, $T=4.2(1), 60(2)$ and $90 \mathrm{~K} \mathrm{(3),} \lambda_{\text {ex }}=473 \mathrm{~nm}$.

XRD-6000 ( $\mathrm{Cu}_{K \alpha}$ radiation, $\left.\lambda=0,154178 \mathrm{~nm}.\right)$ Microphotographs of the samples (coated with a graphite layer) were obtained with an electronic microscope JEM-100 CX II (Jeol). The analysis of the composite structure established that $\mathrm{Al}_{2} \mathrm{O}_{3}$ particles (size 80-220 nm) with irregular morphology were incorporated into $\mathrm{NaAl}\left(\mathrm{MoO}_{4}\right)_{2}$ crystals on its surface (Fig. 1c).

\section{Results and discussion}

Luminescence properties. Photoluminescence and PL excitation spectra in UV and visible (VIS) region of spectra were obtained in 4.2 - $300 \mathrm{~K}$ temperature range. Investigated samples were put in helium flow-type cryostat. PL spectra were analyzed using secondary monochromator/spectrometers: single monochromator MDR-23 and double monochromator DFS-12 equipped with photomultipliers FEU-100 and FEU-79, respectively.

Luminescence spectra of $\mathrm{La}_{1-\mathrm{x}} \mathrm{Eu}_{\mathrm{x}} \mathrm{VO}_{4}$ powders contain narrow spectral lines in the 580 - $720 \mathrm{~nm}$ spectral range. Profiles of the spectra depend on the $\mathrm{Eu}^{3+}$ concentration (Fig. 2a) and do not depend on excitation wavelength in the whole spectral range investigated $(90-330 \mathrm{~nm})$. The peak positions of the spectral lines are located at 587, 621, 687 and $698 \mathrm{~nm}$. The marked lines are better seen for the samples with the lowest Eu concentration ( $x=0.05$, curve 1 in Fig. 2a). These lines are clearly revealed at concentration $x=0.1$ for the samples obtained by the co-precipitation method (Fig. 2a, curve 2). For the samples with $x=0.3$, the noted lines disappear.
The whole spectral region covered by monochromators (350 - $1200 \mathrm{~nm})$ and $4.2-$ $300 \mathrm{~K}$ temperature range was examined in experiments for $\mathrm{NaAl}\left(\mathrm{MoO}_{4}\right)_{2}: \mathrm{Cr}^{3+} / \mathrm{Al}_{2} \mathrm{O}_{3}: \mathrm{Cr}^{3+}$ composites. It was found that the investigated composite samples reveal several emission bands only between 680 and $820 \mathrm{~nm}$. The most intensive bands of this emission peaking at $692.5,693.8$ and $740.6 \mathrm{~nm}$ are denoted as $R_{2}, R_{1}$ and $R$, respectively (Fig. 2b). As Fig. 2b shows, intensity of $R$ band decreases relatively to intensity of $R_{1}$ band when the temperature increases from 4.2 to $90 \mathrm{~K}$.

We ascribed emission of our samples in 740 - $820 \mathrm{~nm}$ region, including the $\mathrm{R}$ band, to emission of $\mathrm{Cr}^{3+}$ ions in $\mathrm{NaAl}\left(\mathrm{MoO}_{4}\right)_{2}$ host, taking into account the recently reported data [6, 7]. In such crystals the $\mathrm{Cr}^{3+}$ ions are in octahedral oxygen coordination occupying positions of $\mathrm{Al}^{3+}$ ions. A sharp intensive emission band of $\mathrm{NaAl}\left(\mathrm{MoO}_{4}\right)_{2}: \mathrm{Cr}$ crystals peaking at $740.5 \mathrm{~nm}$ was identified as the so-called $R$-band of $\mathrm{Cr}^{3+}$ emission [7]. This band originates from spin-forbidden electronic transition ${ }^{2} \mathrm{E} \rightarrow{ }^{4} \mathrm{~A}_{2}$ of $\mathrm{Cr}^{3+}$ ions in octahedral oxygen coordination. Less intensive emission bands in 743 - $770 \mathrm{~nm}$ region (see Fig. 2b) represent the vibronic structure of the $R$ band. A detailed assignment of these vibronic lines was done by Hermanowicz and co-authors [7]. In our samples, where $\mathrm{Cr}^{3+}$ concentrations are comparatively low ( $<0.1$ mas. $\%)$, intensities of all bands of $\mathrm{Cr}^{3+}$ emission in the molybdate host decrease to zero when the temperature reaches $100 \mathrm{~K}$. At higher $\mathrm{Cr}^{3+}$ concentrations ( 2 mas.\%), they also continuously de- 

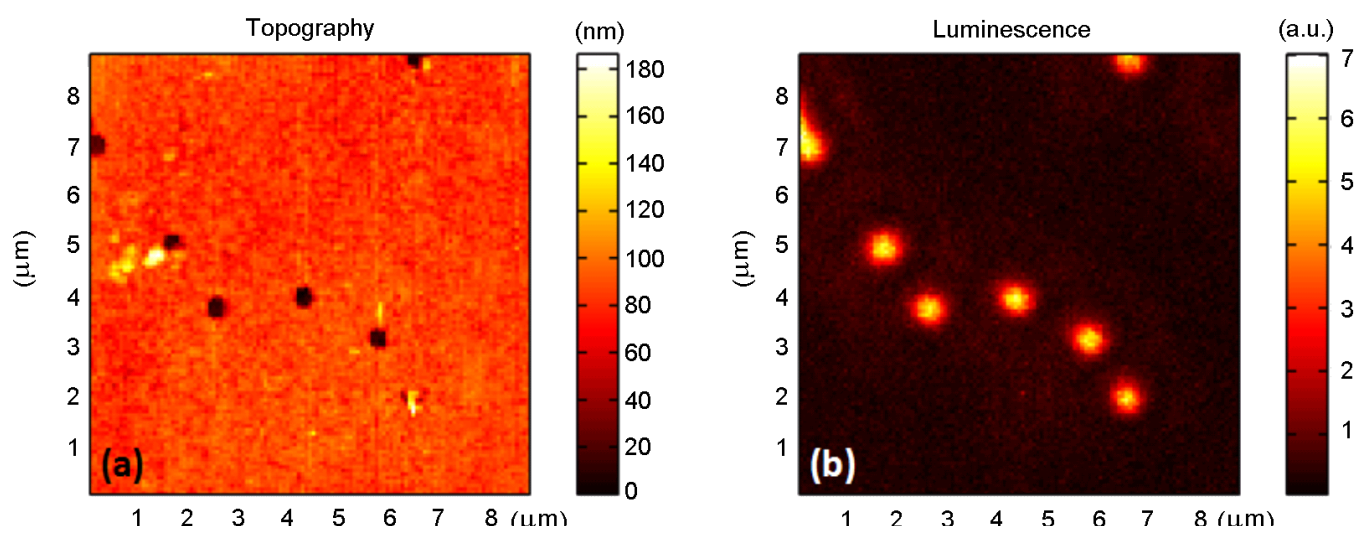

Fig. 3. Topography of the sample surface (a); luminescence image of the particle when scanning the sample (b)
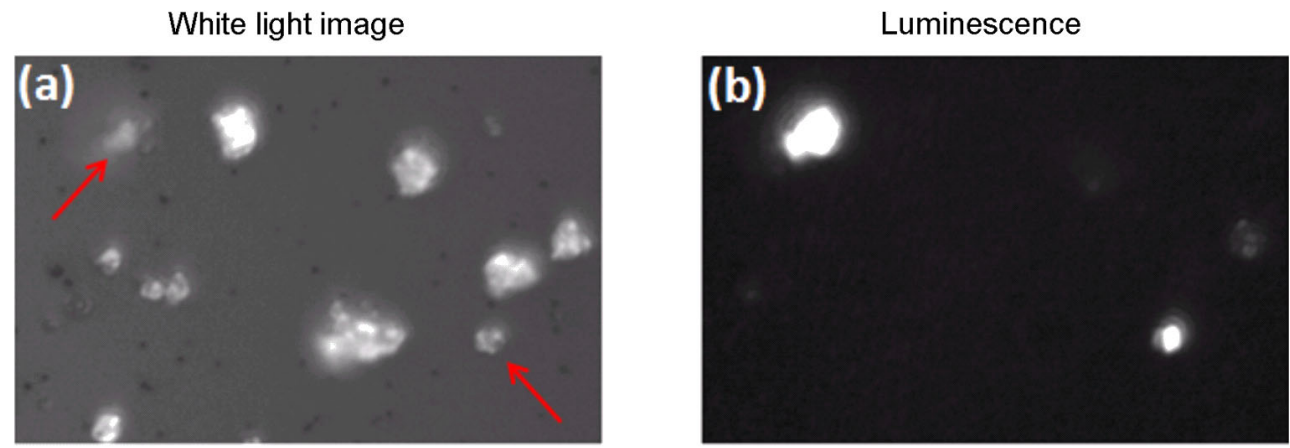

Fig. 4. Microphotographs (image size $44 \mu \mathrm{m} \times 30 \mu \mathrm{m}$ ) of $\mathrm{NaAl}\left(\mathrm{MoO}_{4}\right)_{2}: \mathrm{Cr}^{3+} / \mathrm{Al}_{2} \mathrm{O}_{3}: \mathrm{Cr}^{3+}$ deposited particles on a glass substrate: white light image (a) and luminescence image (b). All the surface was illuminated by the laser beam.

crease with temperature, however being observed up to $300 \mathrm{~K}$ [7].

It should be also noted that $\mathrm{Cr}^{3+}$ ions in octahedral oxygen coordination are often characterized by a pair of $R$ lines due to crystal field splitting of ${ }^{2} \mathrm{E}$ state. However only a single $R$ line is always observed for $\mathrm{NaAl}\left(\mathrm{MoO}_{4}\right)_{2}: \mathrm{Cr}$ and $\mathrm{NaAl}\left(\mathrm{WO}_{4}\right)_{2}: \mathrm{Cr}$ crystals [8], in contrast to other molybdate crystals with the same general formula, e.g. for $\mathrm{KAl}\left(\mathrm{MoO}_{4}\right)_{2}: \mathrm{Cr}$ [7]. This feature was attributed to peculiarities of the site symmetry of Al ions in these crystals.

Scanning probe microscopy of the optical near-field distribution.

The possibility of using submicron particles of the $\mathrm{La}_{1-\mathrm{x}} \mathrm{Eu}_{\mathrm{x}} \mathrm{VO}_{4}$ and $\mathrm{NaAl}\left(\mathrm{MoO}_{4}\right)_{2}: \mathrm{Cr}^{3+} / \mathrm{Al}_{2} \mathrm{O}_{3}: \mathrm{Cr}^{3+}$ composites for near-field optical imaging was investigated. Details of the experimental setup can be found in [9]. A luminescent $\mathrm{La}_{1-\mathrm{x}} \mathrm{Eu}_{\mathrm{x}} \mathrm{VO}_{4}$ particle (diameter between 200 and $400 \mathrm{~nm}$ ) was stuck on a sharp needle (similar to a scanning tunneling microscope tip) using a micromanipulation system. A thin silver layer (thickness about $100 \mathrm{~nm}$ ) with holes of diameter up to $500 \mathrm{~nm}$ was deposited on a $\mathrm{SiO}_{2}$ substrate and was used as a sample on which the optical near-field distribution is studied. The sample was illuminated from the bottom side (in transmittance mode) by a diode-pumped laser with a radiation wavelength of $532 \mathrm{~nm}$. For this experiment, the sample was set on a piezoelectric platform which was moved during the scanning procedure. The tip with the attached particle (microscope cantilever) worked in the tapping mode. The luminescence of the $\mathrm{La}_{1-\mathrm{x}} \mathrm{Eu}_{\mathrm{x}} \mathrm{VO}_{4}$ particle was collected with a microscope objective and sent to a photomultiplier tube after spectral filtering to eliminate the excitation light. The emitted light was detected between $600 \mathrm{~nm}$ and $640 \mathrm{~nm}$ which corresponds to the main luminescence peaks of $\mathrm{Eu}^{3+}$ ions. The topography of the sample and the luminescence intensity were recorded and images were reconstructed with a computer system. During the scanning process, it is expected that the luminescence intensity increases when the particle is located above the holes in the silver film. The main goal of the experiment is to show the possibil- 

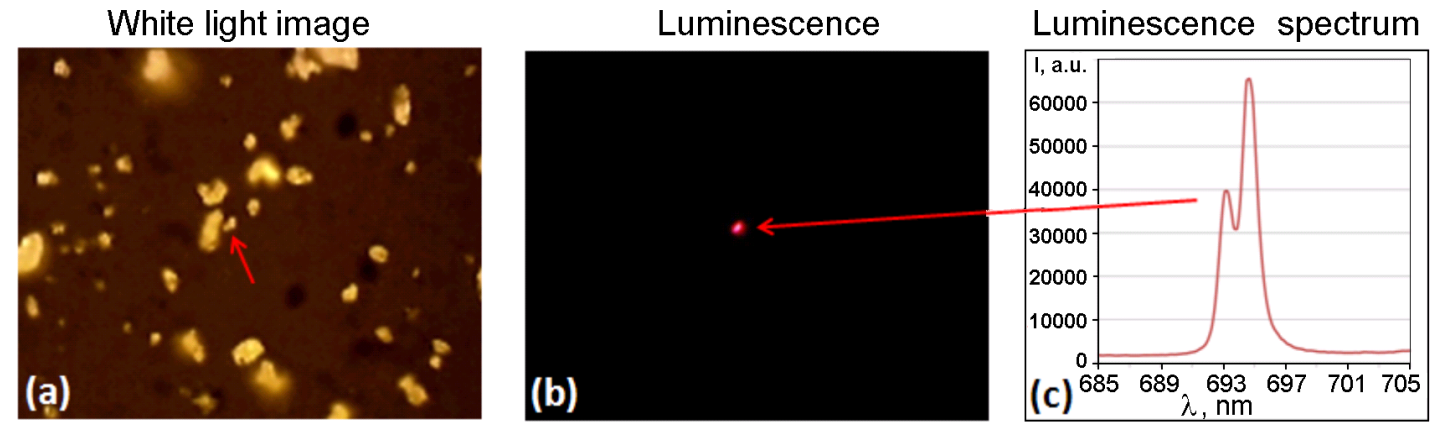

Fig. 5. (a) White light image of the surface with dispersed particles (image size $87 \mu \mathrm{m} \times 69 \mu \mathrm{m}$ ); (b) luminescence image of a single particle indicated by the arrow (only this specific particle was illuminated); (c) PL spectrum of the single particle, $\lambda_{\text {ex }}=405 \mathrm{~nm}$.

ity of using such submicron luminescent $\mathrm{La}_{1-\mathrm{x}} \mathrm{Eu}_{\mathrm{x}} \mathrm{VO}_{4}$ particles for imaging the nearfield in the vicinity of micro and nanostructures illuminated in the visible spectral range.

The sample topography is shown in Fig. 3a. The black regions in the figure correspond to the holes in the silver layer. The luminescence of the particle recorded when scanning the sample (see Fig. 3b) clearly shows a strong increase of intensity when the particle is situated above the holes. No luminescence is recorded when the tip is not situated above a hole. The lateral resolution depends on the particle size and is around $300 \mathrm{~nm}$ in that experiment.

The $\mathrm{NaAl}\left(\mathrm{MoO}_{4}\right)_{2}: \mathrm{Cr}^{3+} / \mathrm{Al}_{2} \mathrm{O}_{3}: \mathrm{Cr}^{3+}$ composites as possible luminescence probes for surface temperature sensors.

The main goal of the experiments described below concerns the possibility to use $\mathrm{NaAl}\left(\mathrm{MoO}_{4}\right)_{2}: \mathrm{Cr}^{3+} / \mathrm{Al}_{2} \mathrm{O}_{3}: \mathrm{Cr}^{3+}$ composites as luminescence probes for temperature measurements with sub-micron spatial resolution. For that, we dispersed the composite on a glass substrate and illuminate the surface with a $532 \mathrm{~nm}$ laser radiation to induce luminescence. A white light microphotography and luminescence image of the $\mathrm{NaAl}\left(\mathrm{MoO}_{4}\right)_{2}: \mathrm{Cr}^{3+} / \mathrm{Al}_{2} \mathrm{O}_{3}: \mathrm{Cr}^{3+}$ composites are shown on Fig. 4. As we can see on the image, the powder is composed of clusters with size ranging between several hundreds of nanometers to several micrometers. Some of the particles, indicated by the arrows on Fig. 4a, are strongly luminescent, and could be used as new thermal probes for temperature measurements. We show in Fig. 5 another example of images of the composite. In that case, the surface was illuminated with a blue laser beam $(405 \mathrm{~nm})$ focused on a specific particle (indicated by the arrow). We also show a spectrum of such particle which clearly indicates two luminescence peaks related to transitions of $\mathrm{Cr}^{3+}$ ions in $\mathrm{Al}_{2} \mathrm{O}_{3}$ hosts (sharp intensive $R$ - lines). Since the relative intensity of these two lines is strongly temperature dependent [10], such particles can be definitely used for preparation of luminescence probes - temperature sensors.

\section{Conclusions}

The results on synthesis and luminescence characterization of luminescent probes for applications in near-field optical characterization and for the measurement of local temperature are presented. It was shown that submicron-sized Eu-doped vanadates particles can be used to develop luminescent probes for near-field optical applications. The chromium-doped composites $\left(\mathrm{NaAl}\left(\mathrm{MoO}_{4}\right)_{2} / \mathrm{Al}_{2} \mathrm{O}_{3}\right): \mathrm{Cr}$ exhibit a strong luminescence that could be used for local temperature measurements with high spatial resolution.

This work was supported by CNRS and NASU agreement project EDC 25191.

\section{References}

1. W. L. Barnes, A. Dereux, T. W. Ebbesen, Nature 424, 824 (2003).

2. E. Pop, S. Sinha, K.E. Goodson, Proc. IEEE, 94, 1587 (2006).

3. H.F. Arata, H. Noji, H. Fujita, Appl. Phys. Lett., 88, 083902 (2006).

4. A. Faraon, J. Vuckovic, Appl. Phys. Lett., 95, 043102 (2009).

5. J. Lee, N.A. Kotov, Nanotoday, 2, 48 (2007).

6. M. Maczka, K. Hermanowicz, P.E. Tomaszewski, et. al., Opt. Mater., 31, 167 (2008).

7. K. Hermanowicz, M. Maczka, P.J. Deren, et al., J. Luminescence, 92, 151 (2001).

8. I. Nikolov, X. Mateos, F. Guell, et al., Opt. Mater., 25, 53 (2004).

9. L. Aigouy, B. Samson, G. Julie et al., Rev. Sci. Instrum., 77, 063702 (2006).

10. Z. Y. Zhang, K. T. V. Grattan, A. W. Palmer, et al., Phys. Rev. B., 51, 2656 (1997). 